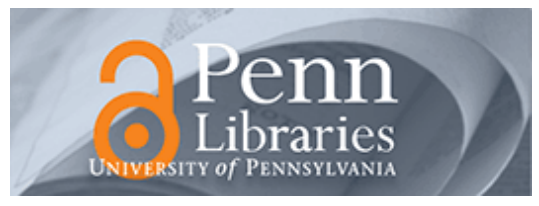

University of Pennsylvania

ScholarlyCommons

Finance Papers

Wharton Faculty Research

3-29-2015

\title{
The Housing and Credit Bubbles in the United States and Europe: A Comparison
}

Susan Wachter

University of Pennsylvania

Follow this and additional works at: https://repository.upenn.edu/fnce_papers

Part of the Finance Commons, Finance and Financial Management Commons, and the Real Estate Commons

Recommended Citation

Wachter, S. (2015). The Housing and Credit Bubbles in the United States and Europe: A Comparison. Real Estate Economics, 47 (S1), 37-42. http://dx.doi.org/10.1111/jmcb.12188

This paper is posted at ScholarlyCommons. https://repository.upenn.edu/fnce_papers/181

For more information, please contact repository@pobox.upenn.edu. 


\title{
The Housing and Credit Bubbles in the United States and Europe: A Comparison
}

\author{
Abstract \\ A house price boom occurred simultaneously in the United States and in a number of European countries \\ from 2003 to 2007, accompanied in each case by an expansion in housing finance. This article considers \\ the role of financial innovation along with incomplete markets in these cycles. \\ Disciplines \\ Economics | Finance | Finance and Financial Management | Real Estate
}




\section{The Housing and Credit Bubbles in the US and Europe: A Comparison}

\section{Susan Wachter*}

The Wharton School, University of Pennsylvania

* Corresponding Author: Dr. Wachter is Sussman Professor of Real Estate and Professor of Real Estate and Finance, Real Estate Department, The Wharton School, University of Pennsylvania, 430 Vance Hall, 3733 Spruce Street, Philadelphia, PA 19104, Email: wachter@wharton.upenn.edu, Telephone: (215) 898-6355. Dr. Wachter acknowledges the assistance from the Research Sponsors Program of the Zell/Lurie Real Estate Center at Wharton. 


\section{The Housing and Credit Bubbles in the US and Europe: A Comparison}

\section{Susan Wachter}

\section{The Wharton School, University of Pennsylvania}

A contemporaneous rise in mortgage debt, securitization, and house prices occurred in the US in the bubble years of 2003-7 (Levitin and Wachter 2012). A house price boom occurred in a number of European countries in these same years. Figure 1 points to 2007 as the approximate peak of the house price bubble ${ }^{1}$ for the US, Spain, Ireland, the UK, the Netherlands, and Denmark. In Europe and the US, the house price boom was accompanied by an expansion of mortgage financing. A rapid expansion of mortgage lending and mortgage securitization of various forms in Europe occurred in these years as well (IMF 2009). The timing of the house price cycle and the credit correlates of these economies mirror those of the US.

Despite these similarities, a granular analysis points to substantial differences in mortgage funding among these economies. Most significantly, in Europe, mortgage debt remained an obligation of the banking system. In contrast, in the US, mortgage risk was offloaded to capital markets through a new "originate to distribute" model of lending. In Europe, the rapid expansion in mortgage debt during the bubble years was funded by bank-held obligations. While securitization was important in both the EU and the US, in Europe, securitization took a different form, with covered bonds being the primary mortgage securitization vehicle. Covered bonds are debt securities backed by cash flows from mortgages. Unlike mortgage backed securities (MBS), covered bond assets remain on the issuer's consolidated balance sheet and remain an obligation of the originating bank lender. They differ from MBS by being backed both by the collateral represented by the home and the bank's contractual obligation to repay investors. MBS, similar to those used in the US, were deployed in 
Europe as well, but the timing of the expansion of this form of mortgage debt was different. While MBS expanded early in the cycle in the US, this expansion occurred after the peak of the price cycle in Europe.

The explanations offered in the literature for the boom and bust cycles in the EU countries and the US do not generally point to or consider what can be learned from this difference. Rather, commentaries typically focus on common global explanations for the housing bubble, such as low interest rates, a savings glut, ${ }^{2}$ and the inelastic supply of real estate. A second strand of the literature focuses on financial innovation, the increased availability of mortgage credit and the simultaneous decline in underwriting standards. ${ }^{3}$ For example, the Financial Crisis Inquiry Commission, whose purpose was the determination of the causes of the crisis, in its majority report, pointed to new forms of credit, regulatory and supervisory failure, with a minority report pointing to the global commonality of excessive leverage spread by new forms of securitization (FCIC 2011). Securitization has been identified as the source of the crisis in part due to misaligned incentives: bank originators of risky debt were not holders of that debt and thus could gain from the revenue generated by issuance of mortgages without incurring risk. Moreover, investors who purchased these securities, particularly "rate investors," relied on ratings rather than analyzing the risk. Many commentators identify the complexity inherent in these new forms of securitization, such as CDOs and CDS, as a causal factor for enabling the debt and price boom. ${ }^{4}$

Were "innovations" in securitization a common cause of the crisis of what was a global cycle? The European experience demonstrates that, to the contrary, the expansion of new forms of mortgage securitization was not a necessary feature of the house price boom. The housing boom in the bubble countries in Europe, in its reliance on bank funding, was similar to the earlier 
real estate boom/bust cycles in Japan in the early 1990s and in the Asian Financial Crisis of 1996.

In Europe, this bank-led funding variously took the form of agency bonds, covered bonds or mortgage-backed securities and their derivatives, as well as wholesale deposits. Increases in mortgage debt in these years were funded through covered bonds or wholesale deposits, at least initially. In Spain, the Netherlands and Denmark, the mortgage debt expansion that accompanied the house price boom was funded, to a large extent, through covered bonds. In Ireland and the UK, short-term wholesale deposit funding was used as the major funding source. MBS was part of the funding increase in these countries, but direct funding that remained on the banks' books was a more significant source of funding.

For example, Ireland, which experienced the most extreme cycle, is emblematic of the bank-led expansion of credit. Irish banks achieved their supply targets through short-term wholesale funding. Securitization did play a role in Ireland's crisis towards the back end of the bubble; however, short-term wholesale funding, made available through the country's accession into the Eurozone, largely drove Ireland's oversupply of credit. Securitization came into play post-Q2 2006, after the Irish housing market had already risen nearly $300 \%$ in the 10 years prior; the peak in the housing prices was to come only a year later in Q2 2007 (European Commission).

The shift from portfolio lending to the "originate to distribute" model cited in the US as a major source of the crisis was not the main story in these European countries; rather, it was bankled expansion of leverage. The off-loading of risk through securitization in a presumed world of assignee liability where investors are also in the blind as to the risk they are taking on is not a sine qua non of a housing bubble (McCoy et al. 2009). Thus, the European experience raises deeper questions about the root source of the crisis and potential 
remedies.

What is common in both Europe and the US and most severe financial crises is the role of housing and real estate. We argue elsewhere (Herring and Wachter 1999) that the key factor in making real estate the asset class behind most severe financial crises is the incompleteness of this market and the difficulty in selling short real estate when its value departs from fundamentals, which allows optimists' pricing to prevail. Using collateralized lending, optimists can continue to bid up prices., whether funded through MBS or bank held assets 5 .

A separate literature on financial accelerators points to credit expansion and its feedback effect on increasing asset prices as the key to the role of debt in the build-up of housing asset-based financial crises (Bernanke, Gertler, and Gilchrist 1999). In this literature, it is the role of the banking sector in ratifying and propagating asset price rises through a bank-led expansion of credit. The source of bank behavior has been variously ascribed to misaligned incentives, short-termism, moral hazard, and information asymmetries (Pavlov and Wachter 2006). The empirical literature focuses on whether bank lending Granger causes price rises, through easing of lending conditions as asset prices rise, or the reverse, with price rises causing lending expansion (Anundsen and Jansen 2013). But even the simple use of current market house prices as a measure of collateral value, despite the fact that these may depart systematically from fundamental value, will result in the same outcome of excess leverage in a bubble. Banks generally rely on appraisals that, in turn, rely on current market pricing and are often under regulatory obligation to do so. The result is the same as in a bank-led expansion of credit, a persistent and growing departure of prices from their fundamental levels, given the lack of short 
selling to contain price rises. The European experience appears to validate this more general explanation.

Optimists' pricing and "irrational exuberance" that occur with backward looking expectations are likely factors in prices departing from fundamentals; neither banks nor home buyers are asset pricers. Rather, banks and home buyers take market prices as given and assume they are accurate. ${ }^{6}$

When prices are out of line, macro prudential policy to contain credit has recently been instituted in several countries, and in the US, stress tests that consider house price vulnerability are in place. But if banks are unable to go beyond current market pricing to determine whether prices are out of line with fundamentals, how will regulators be able to determine this? Beyond these new regulatory stances, are there market-based mechanisms that could be brought to bear in the mispricing episodes?

If the problem at base is a lack of financial derivatives or other market-based instruments to sell short overpriced real estate, is there a potential role for derivatives to signal mispricing and weigh against the market? While the experience with Case/Shiller index futures (Shiller 2012) may suggest this is an exercise in futility, the common fundamental of mispriced real estate and the absence of a short sell instrument suggests that securitization could still be a solution and not only a source of market failure and bubbles.

The key would be for such instruments' pricing to reflect the overall market, as it is the overall market that is potentially mispriced. While the long history suggests otherwise, in fact, new derivatives have been introduced to the US market recently ${ }^{7}$ that do just this and which may in fact succeed in establishing a liquid market to trade overall mispricing 
risk. While the demand to trade individual market price risk has been thin, as might be expected given the fact that real estate ownership is a hedge against price rises, there is a need for a tradable asset to complete this market, particularly to price the risk of a credit default event as debt and prices expand. There is, at least conceptually, room for both market-based and regulatory-based solutions to the common experience of Europe and the US of the correlated excessive expansion of mortgage debt and house prices.

1 The US bubble peaked somewhat earlier in mid-2006 in the US but prices remained elevated through 2007 (Levitin and Wachter 2012).

2 Global savings glut would seem to support the synchronous expansion across countries as well as the decline in interest rates. However, interest rates rose in 2004 as the bubble continued to expand. The global savings glut explanation cannot be the sole factor since many countries, such as Japan and Germany did not in fact experience price increases. The literature on the GSG is mixed with several studies discounting its strength as an explanation (Favilukis et al. 2012).

3 We argue elsewhere that the mispricing of subprime mortgage debt was a key factor, along with poor underwriting and the inelastic supply of real estate (Pavlov and Wachter 2011).

4 See for example Foote et al. (2012) which points to the role of CDOs.

5 " $[E] v e n$ is they earn substandard returns, they are likely to be able to borrow against their capital gains so long as lenders rely on market prices above the fundamental price when determining the value of real estate as collateral" (Herring and Wachter 1999, p.5).

6 Or homebuyers may simply purchase as they can afford or as the prevailing credit conditions allow.

7 See Goodman 2013 for discussion of the STACR and C-Deals instruments. For additional information refer to the following web links:

Freddie Mac Structured Agency Credit Risk (STACR ${ }^{\circledR}$ ), http://www.freddiemac.com/creditriskofferings/stacr_debt.html;

Connecticut Avenue Securities (C-deals),

http://www.fanniemae.com/portal/funding-the-market/credit-risk/conn-ave.html. 


\section{Literature Cited}

Anundsen, André K. and Eilev S. Jansen. (2013) “Self-reinforcing effects between housing prices and credit." Journal of Housing Economics, 22(3), 192-212.

Bernanke, Ben S., Mark Gertler, and Simon Gilchrist. (1999) "The Financial Accelerator in a Quantitative Business Cycle Framework." Handbook of Macroeconomics, 1, 13411393.

European Commission Report. (2012) “Ireland's economic crisis: how did it happen and what is being done about it?" Available: http://ec.europa.eu/ireland/key-eu-policyareas/economy/irelands-economic-crisis/index_en.htm\#1

Favilukis, Jack, Sydney C. Ludvigson, and Stijn Van Nieuwerburgh. (2012) “The macroeconomic effects of housing wealth, housing finance, and limited risk-sharing in general equilibrium." NBER Working Paper No. 15988.

Foote, Christopher L., Kristopher S. Gerardi, and Paul S. Willen. (2012) "Why did so many people make so many ex post bad decisions? The causes of the foreclosure crisis. Fed." Reserve Bank of Boston Public Policy Discussion Paper No. 12-2.

The Financial Crisis Inquiry Commission. (2011) “The Financial Crisis Inquiry Report: Final Report of the National Commission on the Causes of the Financial and Economic Crisis in the United States." Washington, D.C.: US Government Printing Office.

Goodman, Laurie S. (2013) “Housing Finance Reform: Fundamentals of Transferring Credit Risk in a Future Housing Finance System." Statement before the U.S. Senate 
Committee on Banking, Housing and Urban Affairs, Washington D.C., December 10, 2013.

Herring, Richard J. and Susan Wachter. (1999) “Real estate booms and banking busts: An international perspective." Group of 30 occasional papers No.58.

International Monetary Fund. (2009) "Restarting Securitization Markets: Policy Proposals and Pitfalls." In Global Financial Stability Report: Navigating the Financial Challenges Ahead, pp. 77-116. Washington, D.C.: International Monetary Fund.

Levitin, Adam J. and Susan M. Wachter. (2012) “Explaining the housing bubble.” Georgetown Law Journal, 100(4), 1177- 1258.

Levitin, Adam J., and Susan M. Wachter. (2013) "Why Housing?" Housing Policy Debate, 23(1), 5-27.

McCoy, Patricia A., Andrey D. Pavlov, and Susan M. Wachter. (2009) "Systemic Risk Through Securitization: The Result of Deregulation and Regulatory Failure." Connecticut Law Review, 41(4), 493-541.

Pavlov, Andrey and Susan M. Wachter. (2006) "The inevitability of marketwide underpricing of mortgage default risk." Real Estate Economics, 34(4), 479-496.

Pavlov, Andrey and Susan M. Wachter. (2011) “Subprime lending and real estate prices." Real Estate Economics, 38(1), 1 -17.

Shiller, Robert J. (2012) Finance and the Good Society. Princeton, NJ: Princeton University Press. 
FIGURE 1: House Prices Adjusted for Inflation

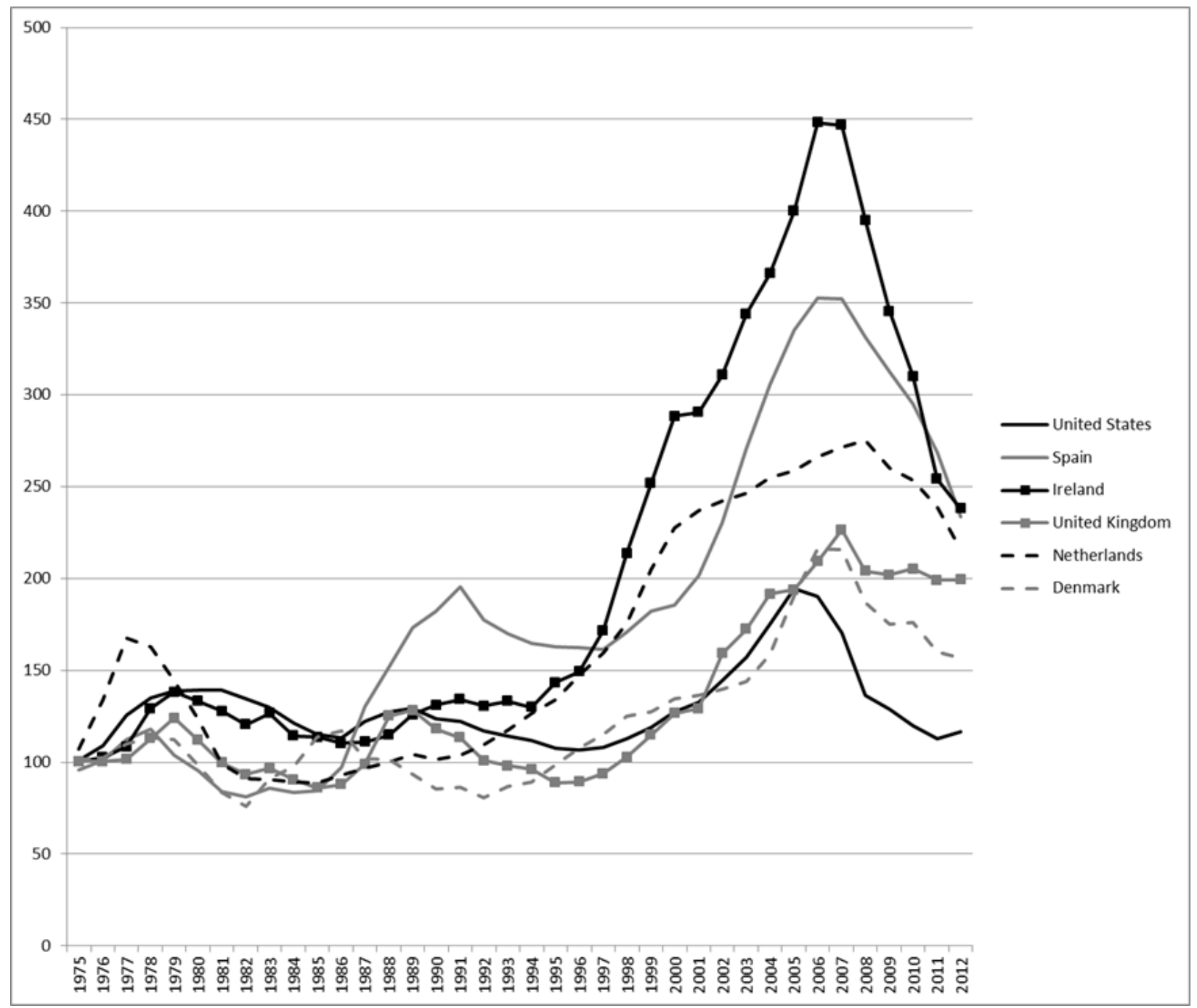

Source: OECD, FHFA 